\title{
Implementation of Pancasila Values in Dayak Hindu- Budha Bumi Segandu Community to Make Good and Smart Citizens
}

\author{
Risladiba Risladiba*, Dadang Sundawa \\ Citizenship Education \\ Universitas Pendidikan Indonesia \\ Bandung, Indonesia \\ *risladiba@student.upi.edu
}

\begin{abstract}
This research is motivated by the problems related to Pancasila values in the life of society, nation and state, which can not be implemented properly. This research uses qualitative approach with case study method. The results of the study show that implementation of Pancasila values in Dayak Losarang community, among others: Dayak Losarang community has a belief with the teachings of "sejarah alam ngaji rasa", the teachings are sourced from nature, Dayak Losarang community has good social relations, both with the surrounding community and with people of Dayak Losarang highly appreciate tolerance, they do not impose the will of others to follow what they believe, even to the children and his wife, the Dayak Losarang community is not involved in the election, the Dayak Losarang community get the same service from the government local, participate in social assistance.
\end{abstract}

Keywords-dayak hindu budha bumi segandu; good and smart citizen; implementation of pancasila values

\section{INTRODUCTION}

The Indonesian nation is a pluralistic nation, so it requires a guideline that can be used as a principle in the life of society, nation and state that is able to bind all components of the pluralistic nation in order not to fall into the split. The only principle that can bind all components of the nation and able to summarize the diversity of the nation's components is Pancasila.

In fact, in the life of society, nation, and state, the values of Pancasila can not be implemented properly, causing various problems. As with the case of intolerance that is rampant, one of them is the destruction of houses of worship occurred in Tanjung Balai, Medan. A total of eight monasteries, Buddhist temples in North Sumatra were destroyed by residents. The incident was on July 29, 2016. The destruction was allegedly because Muslims offended would protest one of the residents regarding worship activities at $\mathrm{Al}$ Makshum Mosque in Tanjung Balai [1].

In addition, there is a problem of lack of awareness of citizens in complying with and implementing the law and the provisions of legislation with full sense of responsibility, which occurred in Cimahi, West Java, where as many as 30 percent of the residents of Sunda Wiwitan in Kampung Adat Cireundeu, Cimahi, Java West, has no identity card or resident identity, such as family card, birth certificate, and marriage certificate [2].

In the district of Indramayu, precisely in the village of Krimun, District of Losarang there is a community settlement that calls itself as a Dayak Hindu Budha Bumi Segandu or otherwise known as "Dayak Losarang". Dayak Losarang community looks unique, one of the teachings in the Dayak Community Losarang Indramayu is a Teachings of Ngaji Rasa that comes from nature. With this teaching they are very respectful of women, socializing openly, without distinction of race, tribe of belief or religion. This community gives opportunity to its members to do the ngaji rasa.

This community places nature as an honorable, inspiring position. They live with a pattern of simplicity, and believe that the world's luxury will only make their lives restless, and wealth is not so important, the most important is patience, honest, righteous, and able to do good with fellow beings. This is based on a shared belief in the truth of the teachings given by their leader, Takmad.

Relevant research with this paper is Damanhuri research in 2016 entitled "Implementation of Pancasila Values as the Nation Character Building Efforts (Case study in Kampung Pancasila Desa Tanjung Sari District Pabuaran Serang)". This research aims to describe the implementation of Pancasila values to the community in Kampung Pancasila. The results showed that the values of Pancasila in the village of Pancasila Desa Tanjung Sari as an effort to build the character of the nation has been running quite well, this is because Pancasila village has been able to apply the values of Pancasila in everyday life. Obstacles that occur because the community still not maximally participate in the application of values Pancasila because there are still many people who are less supportive and cultivate awareness of the importance of planting and the implementation of the values of Pancasila in strengthening the character of society [3].

The values contained in Pancasila were originally a longlived and well-developed civilization long before the state of Indonesia was formed and independent. these values are 
extracted from the unique Indonesian culture and have their own characteristics. The values are then used as a basis in the life of society, nation, and state. Thus, these values should have been ingrained and characterized and characterized by Indonesian citizens. "Pancasila as an umbrella is expected to be accepted by all groups, diverse societies, so that it can coexist peacefully under the umbrella of five basic principles in a state". Pancasila is the most likely alternative in maintaining Indonesian [4].

Based on the background abovementioned, are the purpose of this study is to explore the implementation of Pancasila Values in dayak hindu-budha bumi segandu community to make good and smart citizen.

\section{THEORETICAL REVIEW}

\section{A. Understanding Pancasila}

Pancasila in Sanskrit consists of two words, namely Panca meaning five and Sila which means principle. Pancasila is the formula and guidance of nation and state life for all Indonesian people [5]. Pancasila meaning five basic or five principles is the basis of the Unitary State of the Republic of Indonesia [6]. Pancasila serves as an idealism, then the actions we take are used as a regulative principle in the living order of nation and state [7].

1) Values on Pancasila: Referring to the history long before Soekarno unearthed the value of Pancasila known today, the concept of Pancasila was first documented in the book Sutasoma owned by Mpu Tantular. The book formulates five karma, that is, it is not to be violent, not to steal, not to be spiteful, to lie, and not to get drunk [8].

Tjiptabud explains that in his speech on June 1, 1945, Bung Karno called the principles of Pancasila as the principles of Indonesian life. Pancasila in English is called the five principles. Thus the precepts in Pancasila that give a pattern on the pattern of fikir and the pattern of the Indonesian nation in facing all the problems of life [9].

2) Understanding Good Citizen: Pancasila is the basic ideology for the state of Indonesia and to be a good citizen in Indonesia must be in accordance with Pancasila and the 1945 Constitution. This is what underlies how important Pancasila as a reference or guidance on how to behave into a good citizen (good citizen) in Indonesia [3]. The values contained in Pancasila will teach how to think and act in accordance with the ideology of the state.

3) Understanding Smart Citizen: Smart citizens are intelligent citizens who are capable of thinking analytically, committed and able to involve themselves in the life of society, nation and state [10].

\section{RESEARCH METHODS}

This study uses a qualitative approach. This research will discuss and describe the implementation of the values of Pancasila in Dayak Hindu Budha Bumi Segandu community to realize good and smart citizen.
The method used is case study. The case study approach chosen because of the problem that was used as the focus of this research only happened in certain place that is Dayak Hindu Budha Bumi Segandu community in Krimun Village, Losarang District, Indramayu Regency.

The determination of participants in this study was done by purposive method. Taking the people who are selected by the researcher based on the specific characteristics they have, for example people with a certain level of education, have a certain age, who have been active in the activity community. Data collection through interview techniques, observation, and documentation. Data reduction data, presentation data and conclusions. The technique of testing the validity of the data using source triangulation.

\section{RESULTS AND DISCUSSION}

Pancasila is an integrated ideal in which every part of them is a function and a task. All sila in Pancasila includes every function, meaning and task and purpose specific. Pancasila instructed the nation to achieve prosperity for all Indonesians irrespective of different ethnic backgrounds. All laws or rules in the life of the nation rely on Pancasila. This fact makes Pancasila always enacted in the constitution of life [11].

The Dayak Hindu Budha Bumi Segandu community recognizes that Pancasila is the foundation of the Unitary State of the Republic of Indonesia, in its daily life the Dayak Hindu Budha Bumi Segandu community practices Pancasila values in some ways and does not practice them in some respects.

\section{A. Implementation of the first precepts, "Ketuhanan Yang Maha Esa”}

Beliefs held by the Dayak Hindu Budha Bumi Segandu community very different from the community at large. Where Dayak Hindu Budha Bumi Segandu community has a separate belief with its teachings of natural history of the sense ngaji, according to the Dayak Hindu Budha Bumi Segandu community, the teachings are sourced from nature, that nature is the source of life, nature becomes a place to grow, and the death of all living things including humans. Nature is also the creator of life. Man is born from nature's essence. A baby is born from the meeting of the ovum cell and the sperm of both parents, the cell is created from the juice of food, and human food is derived from nature, then nature becomes the center of the process of life. So, as much as possible the Dayak Hindu Budha Bumi Segandu community doing life activities respect the nature.

\section{B. Implementation of the Second Precepts, "Kemanusiaan yang adil dan beradab"}

Based on the description of the research findings, related to the application of the second principle, that is a just and civilized humanity, that the Dayak Hindu Budha Bumi Segandu community has good social relations, both with the surrounding community and with the outside community who wish to conduct a visit or research in the Dayak Hindu Budha Bumi Segandu community. Dayak Hindu Budha Bumi 
Segandu community has many friends in other areas. According to him, it all depends on what we plant, meaning that if we do good to anyone then we will also get good treatment from anyone, even with people we do not know. Therefore, we must embrace all circles without distinction of religion, race, race, and others. Dayak Hindu Budha Bumi Segandu community develops the attitude of mutual love among human beings, develops mutual tolerance and tolerance, upholds human values, and likes to do humanitarian activities as well as the values contained in the principle of a just and civilized humanity [12].

\section{Implementation of the Third Precept, "Persatuan Indonesia"}

Based on the findings of the research, related to the third precepts, namely the unity of Indonesia, that Dayak Hindu Budha Bumi Segandu community very appreciate tolerance, they do not impose the will of others to follow what they believe, even to the child and his wife they do not impose to following what is adhered to by the Dayak Hindu Budha Bumi Segandu community. The child and his wife are freed to choose what they believe without having to follow the beliefs of their parents. Even with their surroundings they do not spread their beliefs.

Dayak Hindu Budha Bumi Segandu community mingle with the surrounding environment, keeping unity by not imposing wills, tolerating, helping each other with the surrounding community in order to maintain unity and unity of the environment so that there is no division despite different religions, beliefs, habits. It is like the values that exist in the principle of unity Indonesia presented by Kaelan [12].

\section{Implementation of the Fourth Precept, "Kerakyatan yang dipimpin oleh hikmat kebijaksanaan dalam permusyawaratan perwakilan"}

Based on the description of the findings of the research, related to the application of the fourth precepts, which is led by the wisdom policy in representative deliberations, it is known that the Dayak Hindu Budha Bumi Segandu community is not involved in the election. According to the Dayak Hindu Budha Bumi Segandu community, it is because of pity to the unelected candidate or they mention the reason for justice. Because granting the right to vote is the right of each person. But for the wives and children of Dayak Hindu Budha Bumi Segandu community who have been eligible to be registered as voters, they usually voiced their right in the general election. The local government has tried to approach and socialize to the community of Hindu Buddhist Earth Dayak tribe but has not succeeded, for the reasons mentioned above, ie do not want to hurt feelings that are not selected.

\section{E. Implementation of the Fifth Precept, "Keadilan sosial bagi seluruh rakyat Indonesia}

Based on the description of the research findings, related to the implementation of the fifth principle, namely social justice for all Indonesian people, the Dayak Hindu Budha Bumi Segandu community get the same service from the local government, they also get social assistance from the government, because the economic life of the Dayak people Hindu Budha Bumi Segandu can be classified as middle to lower economy, so by the Village Government of Krimun, they are recorded as beneficiaries of poor families, such as health service assistance. In addition, the services provided by the local government are similar to the services provided to other communities.

The Government of the Sub-District of Losarang and the Criminal Village Government Party in providing services to the public, no discrimination shall all be treated fairly. Similarly, with the Dayak Hindu Budha Bumi Segandu community, when there is a wife or children of the Dayak Hindu Budha Bumi Segandu community want to take care of a service, we treat with the same as other communities, they must first meet the requirements that have been determined. The local government hopes that the Dayak Hindu Budha Bumi Segandu community must synergize with government regulations, as well as obey the rules related to population administration, then the regulations on traffic related to the use of helmets when driving a motorcycle. Must comply with government regulations like other communities.

\section{CONCLUSION}

Based on the research findings that have been described related to the implementation of Pancasila values in Dayak Hindu Budha Bumi Segandu community to realize good and smart citizen, shows that the Dayak Hindu Budha Bumi Segandu community know the Pancasila which is the foundation of the Republic of Indonesia, where in daily life, in some cases the Dayak Hindu Budha Bumi Segandu community is implementing the values of Pancasila, but the Dayak Hindu Budha Bumi Segandu community also does not implement the values of Pancasila in some other respects. As well as traditions or customs performed by the Dayak Hindu Budha Bumi Segandu community, in it has the values used as guidance by the Dayak Hindu Budha Bumi Segandu community in running their lives. These values include tolerance, patience, honesty, caring, maintaining brotherhood or unity, respecting the natural surroundings.

\section{REFERENCES}

[1] Tim Redaksi, "Kaleidoskop 2016: Kasus Intoleran di Indonesia Berakhir dengan Perusakan Rumah Ibadah, Jakarta: Okezone," Retrieved from: http://indonesia.ucanews.com/2016/12/22/kaleidoskop-2016-kasusintoleran-di-indonesia-berakhir-dengan-perusakan-rumah-ibadah/. Accesed 28 September 2017

[2] Tim Redaksi, "30 persen Penganut Sunda Wiwitan Cirendeu Belum Kantongi KTP, Cimahi: Kompas" Retrieved from: http://regional.kompas.com/read/2016/08/08/12142551/30.persen.penga nut.sunda.wiwitan.cireundeu.belum.kantongi.ktp, Accesed 4 Januari 2018 pukul 15:50 WIB.

[3] D. Damanhuri, F.A. Bahrudin, W.H. Legiani, and I.N. Rahman, "Implementasi Nilai-Nilai Pancasila Sebagai Upaya Pembangunan Karakter Bangsa," Untirta Civic Education Journal, vol. 1, no. 2, 2016.

[4] N. Somantri, Pembaharuan Pendidikan IPS, Bandung: Rosda Karya, 2006.

[5] P.J. Suwarno, Pancasila Budaya Bangsa Indonesia, Yogyakarta: Penerbit Kanisius, 1993. 
[6] D. Darmodiharjo, Santiaji Pancasila. Surabaya: Usana Offset Printing, 1991.

[7] D. Dwiyanto, and G. Saksono, Pendidikan Karakter Berbasis Pancasila Negara Pancasila: Agama atau Sekuler, Sosialis atau Kapitalis, Yogyakarta: Ampera Utama, 2012.

[8] E.A. Meinarno, and F.M. Sri, "Pembuktian Kekuatan Hubungan antara Nilai-Nilai Pancasila dengan Kewarganegaraan," Jurnal Ilmiah Pendidikan Pancasila dan Kewarganegaraan, vol. 1, no. 1, Juni 2016.
[9] J. Tjiptabud, "Kebijakan Pemerintah dalam Upaya Melestarikan NilaiNilai Pancasila di Era Reformasi," Jurnal Sasi, vol. 16, no. 3, JuliSeptember 2010.

[10] A.A. Wahab, and Sapriya, Teori \& Landasan Pendidikan Kewarganegaraan, Bandung: Alfabeta, 2011.

[11] S. Ediyono, "PSHT Logo as Manifestation of Pancasila Ideological Values," International Journal of Indonesia Society and Culture, vol. 8, no. 2, pp. 309-318, 2016.

[12] Kaelan, Negara Kebangsaan Pancasila, Kultural, Historis, Filosofis, Yuridis, dan Aktualisasinya, Yogyakarta: Paradigma, 2013 